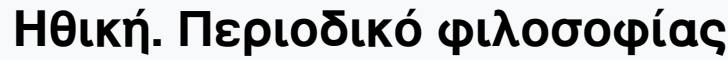

Ap. $13(2020)$

\section{Hөıкท}

The best interests of the child in medically assisted reproduction: A moral-constitutional overview

Fereniki Panagopoulou - Koutnatzi

doi: 10.12681/ethiki.25981

\section{3}

$\triangle$ EKEMBPIO 2020

ETOE IAPYZEOS 200

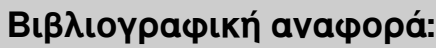

Panagopoulou - Koutnatzi, F. (2021). The best interests of the child in medically assisted reproduction: A moral-

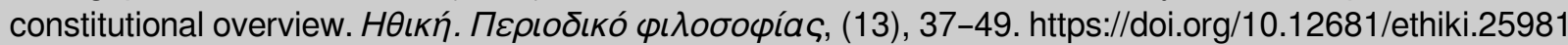




\title{
The best interests of the child in medically assisted reproduction: A moral-constitutional overview *
}

\author{
Fereniki Panagopoulou-Koutnatzi \\ Panteion University of Social and Political Sciences \\ https://orcid.org/0000-0001-7109-7311
}

\begin{abstract}
The infinite and constantly developing options of medically assisted reproduction (MAR) reasonably raise the issue of its permitted range. Proponents of human rights fight for the strengthening of the reproductive right, the access to it by even more people, such as single parents, same-sex couples, elderly women, HIV carriers etc. Still concerning, however, is the fact that the defenders of human rights often forget the rights of the fetus or the child, which cannot be expressed with the same intensity. In the framework of the present study, we investigate the true interests of the child in MAR, in relation to the reproductive right in the light of some borderline cases.
\end{abstract}

Keywords: best interests of the child; medically assisted reproduction; reproductive right; HIV carriers; single-parent family; post-mortem fertilization; same-sex couples

\section{The reproductive right}

The reproductive ability lies at the core of human existence. The decision of whether (or not) to have children constitutes an expression of the free development of personality $^{1}$, as enshrined in article 5 par. 1 of the Greek Constitution. Having children plays a significant role in the development of one's personality, "leading to a reassessment of values and re-definition of the essential elements of one's identity" ${ }^{2}$. The individual right to reproduction includes the right to MAR, without, however, entailing the individual claim of access to all types of methods, as it is confined only to those that are authorized ${ }^{3}$. Therefore, the free development of personality is constitutionally enshrined subject to the restriction that does not encroach upon the rights of others, the Constitution and principles of morality ${ }^{4}$. The constitutional requirement for the non-violation of the rights of others promotes in essence, the protection of the best interests of the child. An unlimited freedom of reproduction is not enshrined, as it is confined to that which does not affect the rights of children.

From a philosophical point of view, it is expressed that it would be more appropriate to speak of "legitimate desire" in the case of assisted reproduction, rather 
than about an explicit right ${ }^{5}$. Furthermore, it is argued that "the calls we make for our reproductive autonomy do not, in any way, presuppose the individual right to autonomy"6. This does not imply that the use of MAR technologies is naturally unacceptable, but rather it indicates that the invocation of the right to reproduction does not automatically justify their use ${ }^{7}$.

\section{The best interests of the child}

The assessment of the best interests of the child as a priority in all decisions concerning thereof, whether made by legislators, administrative authorities, courts or by public or private social welfare institutions, is a key requirement of the International Convention on the Rights of the Child ${ }^{8}$ and of article 24 par. 2 of the Charter of Fundamental Rights of the European Union. It is noted that the Charter does not define the starting point of child protection precisely, subsequently covering the fetal age, too'.

The principle of serving the best interests of the child underpins the Greek law of minors in its entirety (see articles 1511 and 1536 of the Civil Code on parental decisions on the exercise of parental care; articles 1542 and 1558 on serving the interests of the adopted child; article 1648 on serving the child under guardianship; and article 1664 sub-par. a. on serving the child under foster care). In fact, in the case of MAR, Law 3305/2005 stipulates in article 1 par. 2 that, when applying the relevant medical procedures, the best interests of the child that is to be born should primarily be taken into consideration. It is noted that the use of the word "primarily" indicates that in the case of MAR it is not only the interests of the child that are taken into consideration, suggesting that other criteria are also worthy of balancing. In the opposite case, there would be the risk that the law on MAR becomes stricter than necessary, thus limiting the access thereto to very few people ${ }^{10}$.

\section{Examples of conflict between the best interests of the child and the reproductive right}

\section{A. HIV carriers and their right of recourse to MAR methods}

The capability of HIV carriers, as well as of carriers of other contagious diseases, to have access to methods of assisted reproduction has become a matter of concern ${ }^{11}$. As specified in article 4 par. 2 of Law 3305/2005, prior to submission to MAR methods, an obligatory check is conducted regarding, in particular, the potential viral infection from human immunodeficiency (HIV1, HIV2), hepatitis B, C and syphilis ${ }^{12}$. In the case where HIV-positive persons become involved in the application of methods of MAR, a special license is required by the National MAR Authority (hereinafter the "Authority"), (article 4 par. 3 of Law 3305/2005) ${ }^{13}$.

To begin with, it should be noted that for a considerable period of time the licensing Authority was not fully functional ${ }^{14}$. Even after its re-establishment, and for a long period thereafter in the absence of the issuance of the required presidential decree, the Authority was not granting any such license to assisted reproduction centers. As a result of these, these centers proceeded, to an extent necessarily and 
partially also justifiably so, with MAR applications, so as not to halt the reproductive function (and, obviously, also in order not to obstruct the corresponding economic activity deriving thereof through reproductive tourism); however, they did so without the required license and without being subject to the necessary controls with respect to their operating conditions. It is expected that, following the recent issuance of presidential decree No. 10/2016 (18.2.2016), the granting of operation licenses to MAR centers will be normalized.

This issue was, in fact, raised previously before the Authority ${ }^{15}$ in the case of a forty-year-old female HIV carrier and former user of intravenous drugs, who was receiving methadone treatment for addiction at the time of requesting said license from the Authority. She was also a positive carrier of the hepatitis $\mathrm{C}$ virus, for which she was being monitored at a public hospital and was undergoing appropriate antiretroviral therapy, showing great consistency. Due to, most likely, the administration of methadone, the woman presented secondary amenorrhea and, while her husband was seronegative, he had moderate asthenospermia. The couple requested that the Authority grant them license for intrauterine insemination. The Authority clarified that the child's interests are not affected if "the conventional expectations as to its future prosperity" are satisfied and, driven by this reasoning; it held that there are adequate control systems that reduce the likelihood of contagion significantly. With regard to the fact that the average life expectancy of the mother may be reduced, the observation was made that AIDS treatments have evolved considerably and, therefore, the life expectancy of HIV carriers has increased. It was further noted that regarding other diseases associated with reduced life expectancy, the relative legislation does not set restrictions as to reproduction. It is highlighted, however, that the Authority has imposed on doctors an increased duty to provide information to couples regarding risks and the required special care towards the woman.

According to recent studies in the USA, 25\% to $45 \%$ of HIV carriers wish to become future parents ${ }^{16}$. Through the adoption of optimal treatment during pregnancy, the child's risk of infection has been reduced to $1-2 \%$. Studies also indicate that pregnancy does not accelerate the spreading of the virus ${ }^{17}$. Nevertheless, despite these encouraging data, seropositive people often experience resistance on the part of health services, as well as pressure from society aiming towards their exclusion from the right to reproduction. As a result of this social stigma, in addition to their forced sterilization in some jurisdictions ${ }^{18}$, seropositive people were initially reluctant to claim their right to parenthood. This climate is gradually changing, mainly due to encouraging medical research. It was due to this reason that the Ethics Committee of the American Committee for Reproductive Medicine held in 2010 that assisted reproduction centers should extend as much as possible the access provided to HIV carriers who wish to become parents ${ }^{19}$.

It is obvious that the entire project can only be carried out via the creation of suitable facilities for the safe care of the carriers who wish to gain access to MAR units. Towards this direction, article 5 of ministerial decision No. 6901/2015 provides for the safety conditions of reproduction centers, so as to prevent the transmission of the 
infection to healthcare personnel and other persons under treatment.

Given that the risk of infection is actually higher in other diseases than in the case of $\mathrm{HIV}^{20}$, according to current medical knowledge, there is no need for any moral differentiation of the HIV case from other contagious diseases ${ }^{21}$ and, therefore, stakeholders should balance responsibly all the factors before deciding, on the basis of specific information ${ }^{22}$.

\section{B. Creation of a single-parent family}

Article 1456 par. 1 indent b. of the Greek Civil Code recognizes the right of the unmarried woman to be subject to MAR, irrespective of whether or not she is in a free association. The equivalent right of the single man has also been acknowledged in case-law ${ }^{23}$. The legislator allows the establishment of a single-parent family with a single mother or even with a single father. The legitimate question that arises is whether it is in the child's best interests to grow up with only one parent. It is argued that having children as a single parent is contrary to the protection which the State should guarantee to childhood, according to article 21 par. 1 of the Constitution" 24 . The obvious answer to this would be that it is best for the child to have two parents. Oftentimes, however, reality supersedes the ideal family standards and it is not a rare case to see one of the parents disappearing without undertaking his/her obligations towards the child. The reasonable thought is that it is better to regulate something that we do not like, rather than to leave it unregulated and thus open to many abuses against the child. Notwithstanding this, however, certain objections are worthy of attention: Indeed, there are many cases of single-parent families, but our law provides for safeguard provisions in favor of the child's best interests, so that the father acknowledges the paternity of the child born to him, whether voluntarily or involuntarily ${ }^{25}$, by securing at least some financial support on his part, if not his actual physical presence. The reality of a mother raising her child on her own should not be renamed as an unlimited right to create her own family alone.

\section{Post-mortem fertilization}

Article 1457 of the Civil Code provides for the conditions under which fertilization is permitted following the death of the spouse or the $\operatorname{man}^{26}$ with whom the woman lived together in free association. What is permitted in this instance, too, presupposes the existence of medical necessity and, in particular, that the spouse or permanent partner should have suffered from a disease associated with a potential risk of infertility; or that a risk of him dying should have existed; and also that the spouse or permanent partner should have consented to post-mortem fertilization on the basis of a special notarial deed. The question arises whether this provision "does the child an injustice, by planning its development without a father"27. The legal justification is that since single-parent families are allowed, it is preferable, instead of ignoring the technical capability of post mortem insemination, to have it legally regulated, in order for it to be "vested with certain guarantees" ${ }^{28}$. Therefore, any arising questions are primarily focused on the creation of single-parent families, rather than 
on the question of whether post mortem insemination is permitted or not.

\section{The age of parents and donors}

The establishment of an upper age limit for participants in MAR suggests that the legislator is concerned about whether the parents can meet the needs of their child in the best possible way ${ }^{29}$. Furthermore, pregnancy at an advanced age is associated with a higher risk for the woman's health and life and, therefore, these risks of hers also affect the child negatively. Additionally, in the case of homologous artificial insemination, the use of genetic material from parents of an advanced age increases the risk of birth of children with chromosomal aberrations and congenital defects. Therefore, article 4 par. 1 of Law 3305/2005 provides that MAR methods apply to adults up until their age of natural reproductive capacity, making also clear that for women this limit may not exceed the fiftieth year. Despite the explicit legislative provision, case-law has accepted certain deviations, e.g. in the case of granting a license to a fifty-two-year-old woman to gestate the child of her daughter, who suffered from the Rokitansky ${ }^{30}$ syndrome.

The differentiation between men and women, however, causes concern, given that when it comes to adoption a common upper age limit applies for men and women wishing to become prospective adoptive parents ${ }^{31}$. In fact, the view is expressed that this specific limit should be perceived as referring to both members of the cou$\mathrm{ple}^{32}$. This argument is further supported if the shorter life expectancy of the male ${ }^{33}$ is also taken into account.

At the same time, the legislator intervenes in the matter of the disposal of genetic material, defining as the time limit for a male-donor the age of forty years and for a female-donor the age of thirty-five years, providing that these age limits may in some cases be extended until the fiftieth and fortieth year respectively, on the grounds of important reasons, following an Authority's decision (articles 7 par. 7.c and 8 par. 7.a of Law 3305/2005). These age limits, as defined by the legislator, are mostly associated with the "quality and durability of the genetic material, which are impaired over the course of time" 34 .

In article 4 par. 1 of Law 3305/2005, the eighteenth year is defined by the legislator as the lowest limit for recourse to assisted reproduction techniques, presumably so that the parents have the maturity that is required by their demanding parental role. Nevertheless, this rule is not rigid if the childbearing capacity cannot be ensured due to serious disease that may present a high infertility risk.

The age criterion, therefore, as regards the upper as well as the lowest limit, is examined each time on a case-by-case basis, considering the child's best interests as a key factor.

\section{E. Same-sex couples and their right of recourse to MAR methods}

The ability to appeal to MAR methods has been a long-standing request of homosexuals' associations. For the analysis of this issue as a whole, it would be useful to take into account the following:

First, the specific nature of same-sex couples consists in that, under both of 
their forms of composition, they are not able reproduce naturally like heterosexual couples $\mathrm{do}^{35}$. As a result, recognizing the right of reproduction to same-sex couples would lead to the abolition of the subsidiary nature of the therapeutic reproduction which governs our legislation ${ }^{36}$. In particular, according to article 1455 of the Greek Civil Code, the implementation of all reproductive techniques is permitted only in cases of infertility or danger of transmission of hereditary diseases.

Secondly, it should not be overlooked that the homosexuals' associations are gaining more and more ground in social and legal acceptance. The stable cohabitation of people of the same-sex is a social reality that creates social needs, to which the legislator has responded. A characteristic example is the recently enacted Law 4356/2015, with article 1 of said Law providing for the ability to contract a registered partnership irrespective of gender. It is noted, however, that this law does not provide same-sex couples with the option to appeal to MAR.

Thirdly, many same-sex couples have children indirectly, as one member (he/or she) of the same-sex couples may divest him/herself of his/her sexual orientation and appear alone before a MAR center ${ }^{37}$ in order to request assisted reproduction assistance under the pretext of wishing to create a single-parent family (article 1456 of the Civil Code), receive post-mortem insemination (article 1457 of the Civil Code) and/or have recourse to surrogacy (article 1458 of the Civil Code), which leads to raising the child together with his/her same-sex/also homosexual partner, subject to the constraint that the other partner is not legally considered as the child's parent. Moreover, there are many similar types of couples living abroad, in countries where such arrangements are covered by relevant legislation, and it is not unlikely that they may seek to live in Greece at some point. The exclusion of this type of family structure, however, may not be in the child's best interests, especially if said child will have already been recognized as member of a family in one legal system, while this family form is not acceptable in another. Are these children at risk of being regarded as inferior when compared to those being raised by heterosexual parents? The resulting question is who will undertake the care of the child of a homosexual mother or a homosexual father, in the event when the declared single mother or father (where, in actual fact, they were not truly single, but they were declared at the MAR center as such, because the law does not provide them with another more "sincere" alternative) dies, or if he/she is not capable of undertaking the care of his/her children ${ }^{38}$. The partner of the single parent is not authorized by our legal system to undertake the care of said child and, consequently, the child remains legally unprotected.

Fourthly, the best interests of the child should be assessed as a whole and not be invoked solely for the avoidance of structures facing social prejudice. If the reason for the homosexuals' exclusion from MAR services is to preclude the social stigmatization of the child, then the same stigma may torment the child even if the parent is transsexual ${ }^{39}$, incarcerated ${ }^{40}$, a drug dealer, etc.

The reasonable question arising is how can all these data co-exist in harmony with the child's best interests. The legislator is not required to provide solutions to all the questions immediately. As a matter of fact, any changes need to be distilled 
by society and require education and dialogue. The registered partnership option that has now become available to same-sex couples is the first step: moving forward, it may well be the case that the right to same-sex marriage may follow. This does not automatically translate into a recognition of the right to have children. As the ECHR has held, sexual preference does not render a parent incapable or unfit to take care of his/her children ${ }^{41}$. Therefore, all that should be considered is whether the raising of children by parents of the same sex puts the interests of the child in jeopardy. This is a multifaceted problem that cannot be resolved solely by the legislator. The legislator will determine the conditions, relying mainly on the findings of pediatrics and psychology. According to the American Academy of Pediatrics, the best interests of the child are not affected by the heterosexuality or homosexuality of its parents. The American Academy of Pediatrics recommends recognizing marriage and the ability to adopt children irrespective of the gender of the prospective parents ${ }^{42}$. Nevertheless, it seems that this conclusion cannot be transmitted "by remote control" into a different society without it having been distilled properly by society in advance. It is very likely that, if any change occurs swiftly in an unprepared society, the child will be at the center of stigmatization and social prejudice. Therefore, whatever steps may be taken, they should be performed slowly.

\section{Remarks}

\section{A. Choice of terminology driven by the child's best interests}

The legislator's choice to use specific terminology predisposes us about his genuine will, and this is where the terminology referring to "genetic material", "fertilized ovum", "fetus", "embryo", "unborn child", "child", clearly shows that there is no neutral language (on merit) (value-free language) in legal science. Even though the Greek legislator has set the child's best interests as a clause, he denies the use of the term "embryo" by opting for the term "fertilized ovum" instead. The National Bioethics Committee noted in an Opinion on medically assisted reproduction that the use of the term "genetic material" in relation to the period of the early development of the embryo should be avoided ${ }^{43}$. It is noted, however, that the 2015 Cypriot Law on the application of medically assisted reproduction $\{69(\mathrm{I}) / 2015\}$ in Cyprus defines "embryo" as the result of the fertilization of an ovum by a sperm ${ }^{44}$. The difference in terminology between the Greek and the Cypriot law is potentially suggestive of the legislator's intention to provide a different kind of protection. Nevertheless, the true interests of the child require the selection of terminology leading to the highest possible protection. It seems that the term "fertilized ovum", used instead of the term "embryo", implies that the fertilized ovum does not have the same value as the fetus and, therefore, it does not deserve the same protection. There is a reasonable suspicion that the legislator considers this as something which belongs only to those who requested the realization of the relevant medical act ${ }^{45}$. It leads us, however, to the "paradox that man begins to live as a thing and eventually becomes a person ${ }^{46}$." The reasonable question that arises then is whether this differentiation is only valid for extracorporeal 
generated embryos ${ }^{47}$ or for all embryos. Should people who are created under the process of assisted reproduction "be reconciled with the idea that, in the early stages of their lives, they were 'human material' "48?

The legislator's will is that the fertilized ovum is essentially something which belongs to those who asked for the realization of the specific medical act and, for that reason, it is requested of them to decide on its fate ${ }^{49}$. Therefore, the term "embryo in vitro" seems to be more in favor of the child's interest. Subsequently, we should not overlook the fact that "we are facing a new human life, whose characteristics have been irrevocably designated, as a fertilized ovum can no longer be fertilized again by another sperm" 50 . Beyond any other legal concerns, "the treatment of the fertilized ovum as a thing leads us to an ontological confusion, as we blur the boundaries between the inorganic and organic world, overlooking that this distinction is fundamental" ${ }^{\prime 1}$.

\section{B. The issue of recognition and acceptance in the Greek territory of family models that are not permitted in Greece, but which have been established in other countries}

The question raised is how our legal system should treat family structures that have been recognized in other jurisdictions. A relevant example is described in Italy ${ }^{52}$, where a homosexual couple consisting of an Italian and a Spanish woman were lawfully married in Spain and registered their son at the Spanish Registry office. The child was born by heterologous insemination with a donation from a third donor, with the ovum coming from the Italian woman, while the Spanish woman was the carrying mother. The Italian Registry office refused to register the child because, on the one hand, Italian law prohibits heterologous insemination and, on the other hand, it does not recognize the marriage between homosexuals or family structures deriving from homosexual couples. Therefore, the Italian authorities refused to grant the Italian citizenship to the child. It is strongly argued that Italy, being a European Union Member State, should not refuse to recognize the right of free movement $t^{53}$ of European citizens and their families ${ }^{54}$. The issue is resolved as follows: First, under the Treaty, the rights regarding the free movement of persons have been granted to (a) the citizens of the Union and (b) their "family" members. Secondly, both women and the child are citizens of the Union and, therefore, they have the primary right of free movement within the Union, freedom of establishment and equal treatment. Thirdly, the above persons are not family members, because according to article 2 par. 2 sec. b and c of Directive 2004/38/EC, family members are also the partner (he /or she) with whom the Union citizen has contracted a registered partnership, on the basis of the legislation of a Member State, if the legislation of the host Member State treats registered partnerships as equivalent to marriage and in accordance with the conditions laid down in the relevant legislation of the host Member State, and the direct descendants who are under the age of 21 or are dependants and those of the spouse or partner . Thus, Italy is entitled not to recognize the "marriage" or "their" child and validly refuses to grant the Italian citizenship thereto. At the same time, however, they 
are accepted as citizens of the Union (the first partner as a citizen of Italy and the second partner and the child as citizens of Spain) and all the rights that they are entitled to under the Treaty are recognized. In any case, they do not constitute a 'family' in Italy, and this is something that does not, in fact, contrary to EU legislation.

The issue of children without relatives is a major legal issue for the child who is born, and it is linked to its personal circumstances (nationality, kinship) ${ }^{55}$. Laying the foundation of kinship is a human right based on the constitutional protection of human dignity (article 2 par. 1 of the Constitution) and privacy (article 9 of the Constitution, article 8 ECHR), but also on the right of the child to family life (article 8 of the International Convention on the Rights of the Child) ${ }^{56}$. This issue, however, should not only involve the State to which it is addressed, but also the parents or the doctors who break the law, mainly in cases of reproductive tourism ${ }^{57}$. The question that arises is whether the Greek domestic law should show the appropriate flexibility in recognizing family relationships that are valid in other countries or not. This acceptance does not, however, stem from the principle of free movement of persons and their families within the European $\mathrm{Union}^{58}$, as these families are not recognized by the host state. The non-recognition appears on the one hand to be contrary to the best interests of the child, whereas, on the other hand, recognition may have eventually led to an abuse of the non-acceptance of alternative family structures.

\section{By way of conclusion}

Co-existence in the same society requires respect for our fellow citizen. Therefore, no one can claim to be wearing the crown of absolute correctness when it comes to his/ her own position ${ }^{60}$. Even if alternative family structures that differ from those personally chosen by many other people are accepted, particular emphasis should be given on whether these structures actually serve the best interests of the child, so that the audible cries of those who are fighting for their rights do not overshadow the faint voices of the children.

\section{REFERENCES}

* I would like to express my sincere thanks to the Em. Professor of the University of Piraeus, Mr. Panagiotis Kanellopoulos, the Associate Professor of the Faculty of Philosophy of A.U.Th., Ms. Eleni Kalokairinou and the non-salaried assistant Professor of the Medical School of the University of Athens, Dr Eleni Valassi-Adam, for the highly fruitful dialogue herewith.

1. See I. Kriari-Katrani, Biomedical developments and Constitutional Law, Constitutional issues in relation to the methods of assisted reproduction and genetic applications, Sakkoulas Publications, Athens - Thessaloniki, 1994, pg. 47.

2. Ibid., pg. 65.

3. See L. Papadopoulou, Exclusions from medical assisted reproduction under Greek law, in: Changing relationships, Relatives and medical assisted reproduction, B. Kantsa (ed.), (In)Fercit, 2015, http://www. in-fercit.gr/wp-content/uploads/2015/12/Metavallomenes-sheseis.pdf, pg. 225 et seq. (228-9).

4. See Th. Trokana, The application of methods of medically assisted reproduction and the interests of the child to be born, in: Family law in the $21^{\text {st }}$ century from short-term to structural changes, Law and Society in the $21^{\text {st }}$ century, issue 26, Sakkoulas Publications, Athens - Thessaloniki 2012, pg. 119 et seq. (120). 
5. See M. Dragona-Monachou, Medically assisted reproduction: A new field of conflict of rights, Address at the "Meeting" of the National Bioethics Committee of Cyprus, Nicosia, March 3, 2005 (unpubl.). 6. See O. O' Neill, Autonomy and trust in bioethics, transl. by Th. Dritsas, A. Chatzimoisis (ed.), Arsenidi Publications, Athens, 2011, pg. 79-80 and the analysis by E. Kalokairinou, Reproductive autonomy and moral responsibility: Thoughts on the methods of medically assisted reproduction, in: Bioethical Concerns, M. Kanellopoulou-Mpoti/F. Panagopoulou-Koutnatzi (eds.), Papazisi Publications, Athens, 2014, pg. 135 et seq. (137 et seq.).

7. See O. O' Neill, ibid, pp. 79-80.

8. See Ch. Anthopoulos, article 3 [Child's Interest-Third parties rights and obligations], in: The International Convention on the rights of the child and the domestic legal system, interpretation per article, P.Naskou-Perraki/K. Chryssogonos/Ch. Anthopoulos (eds.), Ant. N. Sakkoulas Publications, Athens Komotini, 2002, pg. 44 et seq.

9. See M.-E. loannou, Interpretation of article 24 of the Charter of Fundamental Rights (The rights of the child), in: The Charter of fundamental rights of the EU, Interpretation per article, V. Tzemos (ed.), Nomiki Vivliothiki Publications, Athens, 2015, pg. 304 et seq. (310 et seq.).

10. See E. Kalokairinou, What is a man? Or why is the embryo in vitro not a material to be used?, Introduction in the Conference entitled "Medically Assisted Reproduction in Cyprus", Paphos, September 4, 2015 (unpubl.)

11. This issue led to an acute judicial confrontation abroad. Featured is the decision of the Supreme Constitutional Court of S. Africa Minister of Health v. Treatment Action Campaign, 2002 (5) CC (S. Afr.), www.tac.org.za/Documents/MTCTCourtCase/ConCourtJudgmentOrderingMTCTP-5July2002.pdf, regarding the restriction at medical centers of antiretroviral drugs that prevent HIV transmission from the mother to the child during birth. The Court ordered the government of S. Africa to lift the restriction of a specific ARV drug and to take measures on the voluntary control and consultation for women. According to the Decision of the American Supreme Court Bragdon v. Abbott, 524 U.S. 624 (1998), HIV carriage constitutes a disability, as it essentially prevents reproduction. See criticism on the above decision as being based on outdated medical data by M. Gilman, Applied Feminism and Marginalized Communities, Foreword, 39 University of Baltimore Law Review 2010, pg. 335 et seq. (336).

12. It is noted that according to Recommendations of the American Federal Food and Drug Administration-FDA, male donors of genetic material, who have had intercourse with another man within the previous five years preceding the donation, constitute a high-risk group for the transmission of HIV and hepatitis B. See U.S. Department of Health and Human Services, Food and Drug Administration (FDA), Guidance for Industry: Eligibility Determination for Donors of Human Cells, Tissues and Cellular and Tissue-Based Products (HCT/Ps), http://www.fda.gov/downloads/BiologicsBloodVaccines/ GuidanceComplianceRegulatoryInformation/Guidances/Tissue/UCM091345.pdf. See the analysis of the relevant case-law by L. Cabal/P. Kebriaei, Using Litigation to Address Gender Violations in the HIVI AIDS Context, California: 13 University of California Davis Journal of International Law \& Policy 2006, pg. 9 et seq.

13. It is noted that the legislative condition for the granting of a license by the competent authority excludes any claim of compensation of the infected child against the mother who, although aware of her infection, proceeded with fertilization. On the concerns before the enactment of Law 3305/2005 see, in detail, Th. Papazisis, Civil responsibility and HIVIAIDS disease, Sakkoulas Publications, Athens Thessaloniki, 2003, pg. 309.

14. See F. Skorini-Paparigopoulou, National Authority of Assisted Reproduction: experiences and perspective, in: Current trends of family law, $13^{\text {th }}$ Panhellenic Conference, Company of Judicial Studies Publications, Kavala, October 7-9, 2011, Nomiki Vivliothiki Publications, Athens, 2013, pg. 32 et seq. (35 et seq.).

15. See MAR Authority, Decision 1/2006. Presentation of decision by E. Kounougeri-Manoledaki, AIDS carriers and their right to have descendants: The first decision (no. 1/2006) of the National Authority of Medically Assisted Reproduction, in: Biotechnology Issues-Cloning, Publications of Medical Law and Bioethics, issue 2, Sakkoulas Publications, Athens - Thessaloniki, 2006, pg. 31 et seq. 16. See H. Leggett, Becoming a Positive Parent: Reproductive Options for People with HIV, http://www. sfaf.org/hiv-info/hot-topics/beta/2011-beta-winterspring-fertility.pdf.

17. See H. Leggett, ibid. 
18. See rel. L. Carniak McLaughlin, The price of failure of informed consent law: Coercive Sterilizations of HIV-Positive Women in South Africa, 32 Law and Inequality, pg. 69 et seq. (72).

19. See Ethics Committee of the American Society for Reproductive Medicine, Human immunodeficiency virus (HIV) and infertility treatment: a committee opinion, https://www.asrm.org/uploadedFiles/ ASRM_Content/News_and_Publications/Ethics_Committee_Reports_and_Statements/hivethics.pdf. 20. Ethics Committee of the American Society for Reproductive Medicine, ibid.

21. See S. Gruskin, The impact of reproductive subordination on women's health: Negotiating the relationship of HIV/AIDS to reproductive health and reproductive rights, 44 American University Law Review 1995, pg. 1191 et seq. (1205).

22. This information is of crucial importance, as in the event of a different meaning the parents could claim compensation. See J. F. Hernandez, Perinatal Transmission of HIV: Cause for the Resurrection of Wrongful Life, 27 Journal Marshall Law Review 1994, pg. 393 et seq, T. C. Fappiano, Finding a Legal Remedy for the HIV-Positive Infant: Wrongful Live and Lack of Informed Consent Explored, 12 St. John's Journal of Legal Commentary 1995, pg. 205 et seq.

23. See CoFIAth 2827/2008, CoFIThess $13707 / 2009$, which met the request of unmarried men suffering from incurable oligoasthenoteratozoospermia (OAT), to have a child in a natural way and granted permission for technical reproduction by surrogacy (lending womb). The latest decision, however, was reversed by CoAAth 3357/2010, which accepted, following the birth of twins, that according to the provisions of articles 1457 par. 1 and 1458 of the Greek Civil Code, it appears that, in general, the legislator does not allow unmarried and single men recourse to technical fertilization, as only a woman may get pregnant and she may have a relevant medical inability, in order for recourse to surrogacy to be allowed. According to this decision, this is also the reason why the law does not provide, in general, the option of MAR for unmarried and single men, with whom the child to be born is not related biologically.

24. See I. Kriari-Katrani, The Constitution and the Draft Law of the Special Law-drafting Committee of the Ministry of Justice on "Medical assistance in human reproduction", bioethics.org.gr/Sintagmasxedonomoukriari.doc, pg. 13. Furthermore, according to the ECHR, see Decision Marckx VS Belgium, (13.6.1979, no. 6833/74) there exists a positive obligation on Member-States to allow every child, via legislation, to enter into legal relationships with both its maternal and paternal sides.

25. The acknowledgement of the paternity of a child born out of wedlock can be achieved either voluntarily or by way of court decision (involuntarily), following the filing of a lawsuit on the basis of articles 1479 et seq. of the Greek Civil Code and 620 of the Code of Civil Procedure. The mother or the child is actively entitled to file a lawsuit for the judicial recognition of the child. The mother's right expires after five years following childbirth on the basis of article 1483 par. 1 indent a. of the Civil Code. In the event that the father claims that the mother exercises her right abusively, because she forced him to have sexual intercourse, this allegation is not lawful according to settled case-law. See Areios Pagos 483/1950, NDik 1951, pg. 23. The legal effect of the voluntary or judicial recognition of the child is that the child is made fully equal to the child that is born in wedlock, according to article 1484 of the Civil Code, having exactly the same rights. See F. Panagopoulou-Koutnatzi, "Involuntary paternity", Newspaper of Administrative Law 2015, pg. 108 et seq.

26. With a view to gender equality, post-mortem fertilization may be implemented mutatis mutandis also when a woman dies, as the spouse who survives may submit an application before the competent court for the transfer of the cryopreserved ovum into the body of another woman. On the contrary, it is prohibited to carry out post-mortem MAR when both spouses and/or partners have died, in order to avoid childbirth without parents. See Introduction Report of Law 3089/2002 and also A. Georgiadis, Family Law, Sakkoulas Publications, Athens - Thessaloniki, 2014, pg. 431.

27. See Holy Synod of Church of Greece, The Orthodox review of the assisted reproduction, in:, Bioethics, Synod Texts of Orthodox Churches, N. Koios (ed.), Center of Biomedical Morality and Ethics, Athens, 2007, pg. 87 et seq. (100).

28. See E. Kounougeri-Manoledaki, Objective and subjective options in the law of assisted reproduction, in: Changing relationships, Relatives and medically assisted reproduction, $B$. Kantsa (ed.), (In) Fercit, 2015, http://www.in-fercit.gr/wp-content/uploads/2015/12/Metavallomenes-sheseis.pdf, pg. 109.

29. See M. Milapidou, The age factor and the implementation time of MAR methods, in: Medical assistance in human reproduction, 10 years of implemented Law 3089/2002, Minutes of Conference in honor of 
Professor E. Kounougeri-Manoledaki, April 26-27, 2012, Sakkoulas Publications, Athens - Thessaloniki, 2013, pg. 189 et seq. (198).

30. See CoFIKor 224/2006.

31. See L. Papadopoulou, Exclusions from medically assisted reproduction under Greek Law, in: Changing relationships, Relatives and medically assisted reproduction, (In)Fercit, 2015, pp. 239-240, http:// www.in-fercit.gr/wp-content/uploads/2015/12/Metavallomenes-sheseis.pdf.

32. See M. Milapidou, The age factor and the time of implementation of MAR methods, in: Medical assistance in human reproduction, 10 years of implemented Law 3089/2002, Minutes of Conference in honour of Professor E. Kounougeri-Manoledaki, April 26-27, 2012, Sakkoulas Publications, Athens - Thessaloniki, 2013, pg. 189 et seq. (192).

33. See A. Kalaitzi, Families with elderly parents, in: Assisted reproduction and alternative family structures, Sakkoulas Publications, Athens - Thessaloniki, 2014, pg. 3 et seq, pg. 19.

34. See M. Milapidou, supra note 32, pg. 194 et seq.

35. See Th. Trokana, Human reproduction, Private autonomy and its limits, Sakkoulas Publications, Athens - Thessaloniki, 2011, pg. 215.

36. See Th. Trokana, ibid., pg. 215.

37. See B. Kantsa/A. Chalkidou, "Homosexual mothers": a contradiction in terms? Sexuality and reproduction from the point of view of anthropology, in: Assisted reproduction and alternative family structures, Sakkoulas Publications, Athens - Thessaloniki, 2014, pg. 181 et seq. $(188,195)$. According to the anthropological research carried out by the above authors, homosexual relationships are rarely revealed to the doctor.

38. See B. Kantsa/A. Chalkidou, ibid., pg. 198. The Proposal of 7.12 .2015 by the Ombudsman to the Ministry of Justice regarding regulation of children care in cases of cohabitation contracts with the purpose of establishing the rights of the children who have been born or adopted before or after the conclusion of a registered partnership contract, especially in cases of cohabitation of homosexual partners, in which the children cannot be covered legally in any other way, is also moving towards that direction, http://www.synigoros.gr/resources/20160516-dt--2.pdf.

39. The right of transgendered persons to access MAR does not contravene MAR legislation. See Ch. Sachinidou, Assisted reproduction of transgendered individuals (transsexuals), in: Assisted reproduction and alternative family structures, Sakkoulas Publications, Athens - Thessaloniki, 2014, pg. 125 et seq. (140 et seq.). The contrary was held in the older ECtHR judgement, $X, Y$ and $Z$ VS United Kingdom (22.4.1997, no. 21830/93), which accepted that the refusal of registration of a transgendered person as the father of a child born via MAR does not violate article 8 ECHR.

40. American case-law is extensive on the issue of whether an imprisoned man has the right to recourse to MAR. The following cases reject this right as such: R. (Mellor) v. Secretary of State for the Home Department, Gerber v. Hickman, Goodwin v. Turner. The ECtHR in the case of Dickson VS United Kingdom (4.12.2007, no. 44362/04) accepted that the denial of granting license to spouses who submitted an application thereto in order to have recourse to MAR (in the case in point the man was sentenced to life imprisonment for murder, while his wife was already released at the time of the submission of the application) violates the right to respect of private life. See the analysis of the relevant decisions by $K$. Kipouridou, Assisted reproduction when the spouse is in prison, in: Assisted reproduction and alternative family structures, Sakkoulas Publications, Athens - Thessaloniki, 2014, pg. 107 et seq. The author (pg. 122 et seq.) concludes that when recourse to MAR depends on the legal status of the person, namely whether he is in prison or in a free status, this limits the right to privacy drastically.

41. See ECtHR Decision Salgueiro de Silva Mouta VS Portugal (21.12.1999, no. 33290/1996).

42. See American Academy of Pediatrics, Promoting the well-being of the children whose parents are gay or lesbians, Policy Statement, http://pediatrics.aappublications.org/content/pediatrics/early/2013/03/18/peds.2013-0376.full.pdf.

43. See National Bioethics Committee, Proposal on Draft Law "Medical Assistance in Human Reproduction", 11.10.2002, http://www.bioethics.gr/images/pdf/GNOMES/recom_med_ass_reprod_gr.pdf, Th. A3.

44. See the reservation by D. Roupakia, Proposal on Draft Law "Medical Assistance in Human Reproduction", 11.10.2002, http://www.bioethics.gr/images/pdf/GNOMES/recom_med_ass_reprod_gr.pdf, Th. A3, on the use of the term fertilized ovum, proposing in this respect the use of the term "embryo". 
45. See I. Petrou, Human freedom and the social-moral issues of the origins of life, in: Medical assistance in human reproduction, 10 years of implemented Law 3089/2002, Minutes of the Conference in honour of Professor E. Kounougeri-Manoledaki, April 26-27, 2012, Sakkoulas Publications, Athens - Thessaloniki, 2013, pg. 21 et seq. (31).

46. See $T$. Vidali, When we are "things": the legislation on reproduction and the big distinction in law, in: Medical assistance in human reproduction, 10 years of implemented Law 3089/2002, Minutes of Conference in honour of Professor E. Kounougeri-Manoledaki, April 26-27, 2012, Sakkoulas Publications, Athens - Thessaloniki, 2013, pg. 53 et seq.

47. See I. Kriari-Katrani, The Constitution and the Draft Law of the Special Law-drafting Committee of the Ministry of Justices "Medical assistance in human reproduction", bioethics.org.gr/Sintagmasxedionomoukriari.doc, pg. 7.

48. See I. Kriari-Katrani, ibid., pg. 7.

49. See I. Petrou, ibid., pg. 31.

50. See Holy Synod of Church of Greece, The Orthodox review of assisted reproduction, in: Bioethics, Synod Texts of Orthodox Churches, N. Koio (ed.), Center of Biomedical Morality and Ethics, Athens, 2007, pg. 87 et seq. (94).

51. See E. Kalokairinou, ibid.

52. See M. Ponte, Niente Iscrizione All 'Anagrafe Per II Figlio di Due Madri, Newsp. LA REPUBBLICA, 4.8.2012, http://ricerca.repubblica.it/repubblica/archivio/repubblica/2012/08/04/niente-iscrizione-allanagrafe-per-il-figlio-di.html? ref=search.

53. See article 3 par. 2 of the European Union Convention and article 21 of the Treaty on the Functioning of the European Union, Titles IV and V TFEU.

54. See E. Falletti, LGBTI discrimination and parent-child relationships: Cross border mobility of rainbow families in the European Union, 52 Family Court Review 2014, pg. 28 et seq. (29).

55. See A. Kotzambasi, Children without any lawful ties of kinship, Violation of conditions of assisted reproduction and the consequences thereof, in: Changing relationships, Kinship and medically assisted reproduction, B. Kantsa (ed.), (In)Fercit 2015, pg. 69 et seq. (72), http://www.in-fercit.gr/wp-content/ uploads/2015/12/Metavallomenes-sheseis.pdf.

56. See A. Kotzambasi, ibid., pg. 72.

57. See $A$. Kotzambasi, ibid., pg. 72.

58. Contr. E. Falletti, ibid., pg. 29.

59. Contr. A. R. Ziegler, "LGBT Rights and Economic Migration: Will the Liberalization of the Movement of Persons in Economic Integration Agreements Increase the Need for Common Regional Standards Regarding Civil Status Rights?" in: Equality and justice. Sexual orientation and gender identity in the XXI century, A. Schuster (ed.), Forum edizioni, 2011, pg. 219 et seq. (230).

60. See I. Petrou, ibid., pg. 27 et seq. 